\title{
The Resillience of Indigenous People in The Middle of A Stream of Modernization in The Indonesia - Timor Leste Border Area
}

\author{
Eni $^{1}$, Danu Damar ${ }^{2}$ \\ \{eni-s@fib.unair.ac.id ${ }^{1}$,danu_damar@yahoo.co.id $\left.{ }^{2}\right\}$ \\ ${ }^{1,2}$ Faculty of Humanities, Airlangga University Surabaya, Indonesia
}

\begin{abstract}
The development acceleration of a new urban environment on the borders of Indonesia-Timor Leste is both an opportunity and a challenge for indigenous peoples. The economic development policy of the Special Economic Zone has an impact on the development of the region to be the center of strategic activity on the nation's border. In the NTT region, the development of the area comes with constraints. Using a qualitative descriptive approach, this study examines the emergence of problems in indigenous communities in new urban life. The process of adaptation becomes a natural occurrence carried out by the community when faced with a new environment. But in practice, there are significant differences that require the community to carry out certain strategic planning and strategies to adapt.
\end{abstract}

Key word: Strategic Region, State Border, adaptation strategy

\section{Introduction}

The government's agenda on developing the outer regions has been heard since 2008, but the implementation seems slower than what it is expected. The Medium Term Development Plan (RPJM) 2010-2014 in its implementation is able to change the presentation of the border region into an area that has meaningful dynamics both in terms of space and society. The image of underdeveloped communities, poverty and underdeveloped areas is still closely embedded in the border region. In the NTT region, the border community grows in the socioculture of indigenous people who are still strongly bound by the traditional rules. Entering the end of 2014, the government made a major breakthrough in the management and development of the border area by making discourse changes on the outermost side to become the country's leading regions. As the consequences, there were developing and managing change into a new environment. Changing environment.

Environmental changes in several phases have an effect on the emergence of adaptations from local communities. The new environments induced new challenges as well as opportunities which determine the patterns of local communities. In some cultural interactions, there would often occur lags or significant differences between two or more cultural stakeholders. The differences become the beginning of a culture shock. Some of cultural communities make strategic efforts in this situation. Adaptation strategies are their effective solution. 
Since 2009, the state border area of Indonesia-Timor Leste began to form a new urban environment that accompanied the politic separation of two countries. The modern life patterns have been felt since the implementation of the 2014-2015 border area development program which accompanied by the formation of a new environment. In the other side of the area is inhabited by indigenous community which still firm in tradition and living in a low level of life. The community becomes an important element that is directly involved in the new environment. This situation makes a contradiction and raises various problems; How the community be able to answer the challenges of new life as an opportunity for their development?; What kind of adaptation process is done in a new environment?; And how is the impact on the value of life as a traditional community living in the urban environment at the outermost region?

The qualitative descriptive approach in this study is used to explore and understand the meaning of individuals or groups in a social or humanity problem and try to resolve the complexity of a problem which is obtained through a method of inductive observation. According to Kaplan and Maner, emic and ethic approaches can be used in cultural research (Kaplan: 2002) [1]. Emic approach in this study is used to collect the field data based on the direct findings according to the views of the local community. Meanwhile, ethic approach help to categorize cultural phenomena by referring to theories cultural change and cultural adaptation related.

The data were collected by observation which involved-participant (Jurgensen, 1989)[2]. Other than observation and involved-participant, the data collection was done through indepth interviews with informants. The interview techniques from Scale is used in this study (Scale, 1999)[3], which include three steps; (1) Listening to stories, this technique provides space for informants to share their experiences as an actors in the patriarchal culture. (2) Paying attention to behavior (observing behavior). Observations involved to provide non-oral information that can reinforce the testimony of the informants as a cross-check material and as an attitude and behavior data material. (3) Examines the historical footprint of research objects.

Cultural adaptive strategy analysis in this study uses Adaptive Culture Strategy Theory from Kim (Kim, 2001: 153)[4]. According to Kim, there are 2 stages of adaptation; cultural adaptation and cross cultural adaptation. Cultural adaptation is the basic process of communication that is conveying the message, the medium and the recipient of the message, so there will be encoding and decoding process. This process is identified as the level of transformation that occurs when individuals move into a new environment which can be understood by the group involved.

\section{Result And Discussion}

\subsection{Indigenous Peoples Living at the Indonesia-Timor Leste Border}

The NTT border is partly a land border which coincide directly with the territory of Timor Leste, even in the TTU and TTS areas which forming the enclave of Oecusse Timor Leste. (BPPD Kabupaten TTU: 2016). The region consists of around 60 villages inhabited by various indigenous communities (BPS 2014)[5]. It is recorded that there are at least 12 indigenous groups in the border area of Wini, consisting of the Meko tribe, the Kutet tribe and the Kase tribe. They grow in a strong tradition which arrange their way of life. According to 
Parsudi Suparlan, quoted by Anan Mutakin (200: 1)[6], the indigenous community is a unity of human social life which occupying a certain area with behavior regularity in social life. Moreover, it also has social institutions that become habits in the culture they have together.

Thus, people at the border circle are living in a socio-cultural environment that is built by the bond of indigenous values to regulate their lives as a product of local wisdom. Politically, it is undeniable that the indigenous people are within the sociopolitical ties to Indonesia.

When Indonesia was actively making efforts to transform the borders of Wini and to make Wini a Special Economic Zone, a new environment was shaped and would be faced by these indigenous peoples. This environmental order according to Lili Weri can be a basic reason for the culture shock phenomenon in some indigenous communities in NTT.

\subsection{Environmental Changes in the Indonesian Border Area}

Social change as a concept can be understood in two senses. The first definition can be defined as a change in social structure, such as population, composition or balance of parts of the population. Second, social transformation can be interpreted as processes of change which include economics, politics, and culture or in other words the concept of social transformation can be understood as "any alteration in structure" (Burke, 1980: 80)[7].

In the NTT border region when the Nawacita program was implemented at the end of 2015 by making major changes, various forms of cultural shock occurred in the indigenous communities. Although there is no open cultural conflict, it is the reason for indigenous communities to make strategic efforts to deal with these changes. Indigenous peoples are included in the flow of progress rounds that have been rolled out by the government. The culture shock condition will be the initial symptom followed by cultural adaptation. In the next stage, a person or community will take the decision's momentum to adapt. The cultural shock phenomenon at the indigenous community occur when faced with new environmental changes (Lili Weri: 2004, 9-15)[8].

At the doors of the BPLN (Cross-Border Post), the area development has been carried out using a security and prosperity approach. As well as the environment, especially the physical environment. However, there are things that are important but have not maximally touched in the environmental approach, namely socio-cultural environment. It is important because the border area does not only speak in the dimensions of space but also in the human dimension. The meaning of the border region where there are humans with accompanying activities and patterns of interaction patterns that are built with the socio-cultural environment and interaction and communication that are built with the dimensions of the physical environment. The socio-cultural environment will form the activities of community activities with their community identity and communication built with the surrounding environment. In an effort to build interaction and communication with the environment, management and strategic strategies are needed to establish a harmonious relationship in the development of border areas.

In this case, the indigenous people do several steps by activating and cooperating between traditional and government elements. This effort is carried out by activating indigenous communities as a communication tool between the needs and demands of the community by harmonizing state interests. Indigenous elements that are activated by both the community leader and officials below, which isTobu. (Interview: Usi Meko 2019)[9]

Empowering local wisdom and strengthening socio-economic potential of indigenous peoples to actively contribute to economic and social development. These efforts continue to make the basic indigenous rules to be maintained by making adjustments in several levels. 
This effort seems to have received a positive response from the government, in this case BNPP. BNPP involves the development and management of border areas without leaving the active role of the community. The policy basis for involving the local community in the management of the area in East Nusa Tenggara is clearly stated in Presidential Regulation No. 179 th 2014 concerning the management of the spatial layout of the Country's Border Area in the Province of East Nusa Tenggara concerning the community as one of the elements in the management of the countries Border.

Since the nawacita program has been launched, urban and modern life gradually formed in the border area. The idiom for the situation is "city life in the midst of slums and disadvantaged people." The emergence of border areas is central to social and economic activities capable in forming the center of the crowds whose impact is quite significant. At least the border area is formed into the place where activity of goods and human mobility have done. For example, when the government stipulates the border area of Wini with the status of Special Economic Zone Development (SEZ), it supports Wini to grow into a new form of environment with economic activity as its main driver.

1. the government has built public facilities such as two-lane highway as far as tens of kilometers in Wini;

2. develop the Wini port with the Belu Regent to encourage the border area to become a special economic zone,

3. construct several numbers of storage warehouses for goods

4. an airport development plan that is located at the border between two Belu and Wini districts, namely Biboki Anleu District (TTU) and Kakuluk Mesak (Belu) which of tens of kilometers.

5. Construct cross-border posts

6. Implementation of the Telkomsel telecommunications network

7. The Atambua Crossborder Festival is held as a mandatory agenda visited by tourists, especially the Timor Leste people. Moreover, this event introduce Atambua as one part of Indonesia with its beautiful and exotic natural wealth as a form of Border Tourism

With the establishment of Wini as a special economic zone, this area has become the place for the emergence of activity centers and formed "new urban areas". In NTT other than the border in Kupang Regency, the "urban" area of border has been formed in the Montain Door which is integrated into the city of Atambua. The border door area which will be developed into "Perbatan City is Napan.

The development of the cities on the border area has been carried out by the Malaysian government. This country made the border area the front guard by strengthening the socioeconomic field. The strategy carried out by Malaysia in the Indonesian-Central Border turned out to be able to make the Malaysian border region a reference for the economic activities of most of the Indonesian people. Even an idiom present "Garuda in my chest, Malaysia in my stomach".

The government's strategic plan in forming the Economic Zone and forming "Cities on the border" are very effective for social welfare and economic equality which very much needed by the people in the border regions. The presence of the country in transforming nonstrategic areas into strategic areas requires active anticipation of the local community.

Utilization of the area as a center of goods and human activities has experienced a significant increase. Data from BPS shows that the number of foreign tourists visiting Indonesia through the Cross Border Post (PLB) for the period of May 2017 has reached about 156.05 thousand visits. This number increased by 722.38 percent compared to the same period in the previous year (BPS 2018)[10]. 
Behind the achievements at the door of the Borderline progress, several problems have arisen in the local community. Problems are rooted in differences between new and local cultural values. The problems which considered as not correspond to the traditional values include: (1) Changes in the structure of modern bureaucracy shift the structure of traditional bureaucracy. Modern governance bureaucracy will dominates, especially those related to government bureaucracy in the PLB. Traditional bureaucracy eventually only developed at the local level within the indigenous community. Finally, the custom rules only implemented in the internal part of the tribe. Likewise the role of the customary head becomes limited by roles in the new leadership structure. (2) The limitation of human resources in the border region makes their involvement in the process of change not optimal. Moreover, limitation of formal education facility in the communities of Border region make it worst. This can be seen from the very limited availability of schools, especially for the secondary school level. This condition makes local communities unable to take a maximum role in their environment. (3) The lack of human resources availability from local communities encourages groups of migrant communities to fill this gap, both in the bureaucratic order and in taking on the strategic role of the economy. The emergence of new community groups threatens the marginalization of the local communities of their own territory. Furthermore, the emergence of new groups of society as a product of the "urban" community amidst the minds of the village community.

The problems which currently being faced by local communities in Wini is a picture which is currently running in the community of "cities" in the border regions of the IndonesiaTimor Leste PLB Wini. However, there are efforts made by indigenous people, including (1) re-activating customary functions in accordance with traditional organizational structures. Indigenous peoples revived Tobo's function as a position in charge of communicating with the government so it was expected to be an effective medium of community aspirations. (2) open themselves to make adjustments in the changes by adhering to the standard rules that can still be accepted by customary rules.

\section{Conclusion}

The development of the Indonesia-Timor Leste Border Area in Wini PLB was able to change the face of the country's outermost region into a new environment in the national border. Economic activity is the main driver of city formation accompanied by changes in socio-cultural aspects which makes communities at the border as important elements which directly involved. Local communities are faced with a new environment that is different from their old environment.

New different circles has risen to several problems. The problem of shifting old values, the replacement of the dominant by new roles in the organizational structure and modern bureaucracy, as well as the globalization of information and other supporting facilities open the chance newcomer in Wini border environment.

Community involvement efforts have been made even though the development is still not maximal. Revitalization of customary values is intended as an internal effort to provide a basis for community members to continue to use customary values as part of making changes. The customary elements also tried to communicate with the authorities and interest groups as an effort to actively take a role in the process of developing border areas. 


\section{References}

[1] Kaplan, dkk.1999,Teori Budaya, ( Terjm. Landung Simatupang), Yogyakarta: Pustaka Pelajar.

[2] Danny L. Jurgensen, 1989.. Participant Observation, A Methodology for Human Studies. Applied Social Research Methods Series Volume 15 (Newbury Park, London, New Delhi: Sage Publications.

[3] Scale 1999, dalam Eni Sugiarti, Dinamika sosial Ekonomi di Perbatasan Indonesia-Timor Leste : Pasar Tradisonal Bersama di Perbatasan Timor Tengah Utara-Oesilo Oecusse Timor Leste, dan Mobilitas soaial Masyrakat, , Laporan Penelitian PUPT tahun 2016 Universitas Ailrangga

[4] Kim, Young Yun, 2001 Becoming Intercultural : An Integrative Teori and Cross Cultural Adaptation USA : Sage Publication.

[5] Badan Pusat Statisik Kecamatan Insana Utara tahun 2014

[6] Persudi Suparlan, 2004, Hubungan Antar Suku Bangsa, Masyarakat dan Kebudayaan Perkotaan , Jakarta, YPKIK.

[7] Burke, Peter, 1980, History and Social Theory, Ithaca New York: Cornel Univerity Press

[8] Alo, Lili Weri, 2004 , Komunikasi Antar Budaya, Jakarta Pustaka Pelajar.

[9] Interview by Usi Meko, Manamas Timor Tengah Utara , 9 August 2019

[10] Badan Pusat Statistik, Insana Utara dalam Angka 2018. 